\title{
Biological and trophic consequences of genetic introgression between endemic and invasive Barbus fishes
}

\author{
Vanessa De Santis (i) - Silvia Quadroni (i) Robert J. Britton (i) - Antonella Carosi (iD) \\ Catherine Gutmann Roberts (D) - Massimo Lorenzoni (i) - Giuseppe Crosa (iD) \\ Serena Zaccara
}

Received: 12 January 2021 / Accepted: 13 May 2021/Published online: 26 May 2021

(C) The Author(s) 2021

\begin{abstract}
Genetic introgression with native species is recognized as a detrimental impact resulting from biological invasions involving taxonomically similar invaders. Whilst the underlying genetic mechanisms are increasingly understood, the ecological consequences of introgression are relatively less studied, despite their utility for increasing knowledge on how invasion impacts can manifest. Here, the ecological consequences of genetic introgression from an invasive congener were tested using the endemic barbel populations of central Italy, where the invader was the European barbel Barbus barbus. Four populations of native Barbus species (B. plebejus and B. tyberinus) were studied: two purebred and two completely introgressed with alien B. barbus. Across the four populations, differences in their biological traits
\end{abstract}

Supplementary Information The online version contains supplementary material available at https://doi.org/10.1007/ s10530-021-02577-6.

V. De Santis $(\square) \cdot$ S. Quadroni · G. Crosa · S. Zaccara

Department of Theoretical and Applied Sciences,

University of Insubria, Varese, VA, Italy

e-mail: v.desantis1@uninsubria.it

R. J. Britton - C. Gutmann Roberts

Life and Environmental Sciences, Bournemouth

University, Poole, Dorset, UK

A. Carosi - M. Lorenzoni

Department of Chemistry, Biology and Biotechnologies,

University of Perugia, Perugia, PG, Italy (growth, body condition and population demographic structure) and trophic ecology (gut content analysis and stable isotope analysis) were tested. While all populations had similar body condition and were dominated by fish up to 2 years of age, the introgressed fish had substantially greater lengths at the same age, with maximum lengths $410-460 \mathrm{~mm}$ in hybrids versus $340-360 \mathrm{~mm}$ in native purebred barbel. The population characterized by the highest number of introgressed B. barbus alleles $(81 \%)$ had the largest trophic niche and a substantially lower trophic position than the other populations through its exploitation of a wider range of resources (e.g. small fishes and plants). These results attest that the genetic introgression of an invasive congener with native species can result in substantial ecological consequences, including the potential for cascading effects.

Keywords Trophic impacts $\cdot$ B. plebejus . B. tyberinus $\cdot$ B. barbus - Interspecific hybridization · Hybrid vigour

\section{Introduction}

Interspecific hybridization is a widespread process in animal communities that has been suggested to negatively affect species through depressing the fitness of hybrids (i.e. outbreeding depression) 
(Rhymer and Simberloff 1996). However, growing evidence now suggests that hybridization has driven speciation in a wide range of taxa (Seehausen 2004; Baack and Rieseberg 2007; Svardal et al. 2019) and, consequently, its role in evolution has been reconsidered.

While being an important evolutionary force, introgressive hybridization can create considerable conservation issues (Allendorf et al. 2001; Brennan et al. 2014), especially when anthropogenic activities, such as habitat modification (e.g. Chafin et al. 2019) and species introductions (e.g. Ward et al. 2012), result in the mixing of previously isolated species. This is particularly true when one of the formerly isolated species is an endemic with a narrow distribution range and/or the two species are taxonomically similar (Huxel 1999; Hänfling et al. 2005). Hybridization can even trigger the invasion process (Hovick and Whitney 2014; Roy et al. 2015), with hybrids potentially outperforming parental taxa through the novel combination of parental traits (Seehausen 2004) or expressing new traits through transgressive hybridization (Rieseberg et al. 1999).

Invasion driven hybridization, resulting from the introduction of alien species into communities where taxonomically similar native species are present, is increasingly recognized as a threat to the genetic integrity of many native species (Huxel 1999; Gaskin and Kazmer 2009; Kovach et al. 2015). Current knowledge on the genetic introgression of invasive and native species has tended to focus on the underlying genetic mechanisms, with less consideration given to how the introgression alters the functional traits and ecological interactions of the hybrids in relation to their parental species (Matsuzaki et al. 2010; Toscano et al. 2010; Hayden et al. 2011).

A model to study the ecological consequences of invasive hybridizing species is represented by the European barbel Barbus barbus (Linneus 1758), a cyprinid riverine species native to central Europe, that has been introduced into other European areas, including Italy (Bianco and Ketmaier 2001) and Western Britain (Wheeler and Jordan 1990), via anglers or angling orientated stocking events. While this invader has no congeners present in Britain, limiting the genetic introgression concerns (Britton and Pegg 2011), four native Barbus species are present in Italy. Two of these, B. caninus Bonaparte 1839 and B. balcanicus Kotlik, Tsigenopoulus, Rab and Berrebi
2002, inhabit the upper reaches of rivers. In contrast, B. tyberinus Bonaparte 1839 and B. plebejus Bonaparte 1839 , populate the middle/lower reaches of Italian rivers, in habitats that are also preferred by $B$. barbus (Carosi et al. 2017). All these native Italian barbels are generalist benthivores and so their diet tends to be dominated by benthic macroinvertebrates (e.g. dipteran larvae; Tancioni et al. 2001; Piria et al. 2005; Corse et al. 2010), with proportions of other food items varying according to availability (Piria et al. 2005).

Hybridization between Barbus species has been widely documented as both natural events (e.g. Tsigenopoulos et al. 2002; Buonerba et al. 2015), and following invasions (Meraner et al. 2013; Geiger et al. 2016). When hybridization occurs in natural contact zones, it is usually limited to that area but, in the case of the genetic admixture between invasive $B$. barbus and native Italian barbels, it has been found to be more widespread, with a tendency to form a complete 'hybrid swarm' (e.g. Meraner et al. 2013; Zaccara et al. 2014). Moreover, these Barbus hybrids are fertile and a range of hybrid forms may be present across multiple generations, including backcrossed individuals (Meraner et al. 2013). In addition, hybrids between the exotic $B$. barbus and endemic congeneric species are suggested as having enhanced somatic growth rates than their purebred parental species (Meraner et al. 2013; Carosi et al. 2017). There is thus the possibility that hybrid barbel have a fitness at least equal (or higher) to the parental species (Pfennig et al. 2007). Given that this introgression can result in morphological differences between the purebred and hybrid forms (Zaccara et al. 2020), questions have arisen over how morphological shifts alter the interactions of hybrids with other species and their environment, including their utilization of trophic resources.

Therefore, the aim of this study was to test the biological and trophic consequences of genetic introgression across populations of endemic Barbus species invaded by $B$. barbus, with comparisons to uninvaded populations. The objectives were to test differences between purebred and introgressed Barbus populations in relation to their: (1) somatic growth rate, body condition and population demographic structure (i.e. biological traits); and (2) diet composition and trophic ecology (e.g. trophic niche size and trophic position), enabling the assessment of their 
functional roles (Davis et al. 2012; De Carvalho et al. 2019; Pacioglu et al. 2019). We posit that: (1) introgressed fish will have biological traits at least equal to those of the parental species; and (2) introgressed fish will have larger trophic niche sizes that differ in their trophic positions compared with native parental species, with this potentially related to alterations in their functional morphology (Zaccara et al. 2020).

\section{Materials and methods}

Sampling strategy and sites description

Sampling was performed at four representative sites located in central Italy (Fig. 1; Table 1). Two of these were selected where impassable weirs have prevented $B$. barbus invasions and thus purebred populations of the endemic B. tyberinus and B. plebejus were present (Zaccara et al. 2020). They were located in the species respective distribution range: the Tuscany-Latium (TL) and the Padano-Venetian (PV) ichthyogeographic districts for B. tyberinus and B. plebejus respectively (Bianco 1995). The other two sites were located within the same river catchments (see below) but where each of the two native species has introgressed with B. barbus (Zaccara et al. 2020) following its invasion of the middle and lower reaches since at least 1998 and 2005 (i.e. their first detections in these basins; Lorenzoni et al. 2010; Lorenzoni and Esposito 2011) in TL and PV districts respectively. Therefore, for each ichthyogeographic district, there was one purebred (" $p$ ") population (located in the
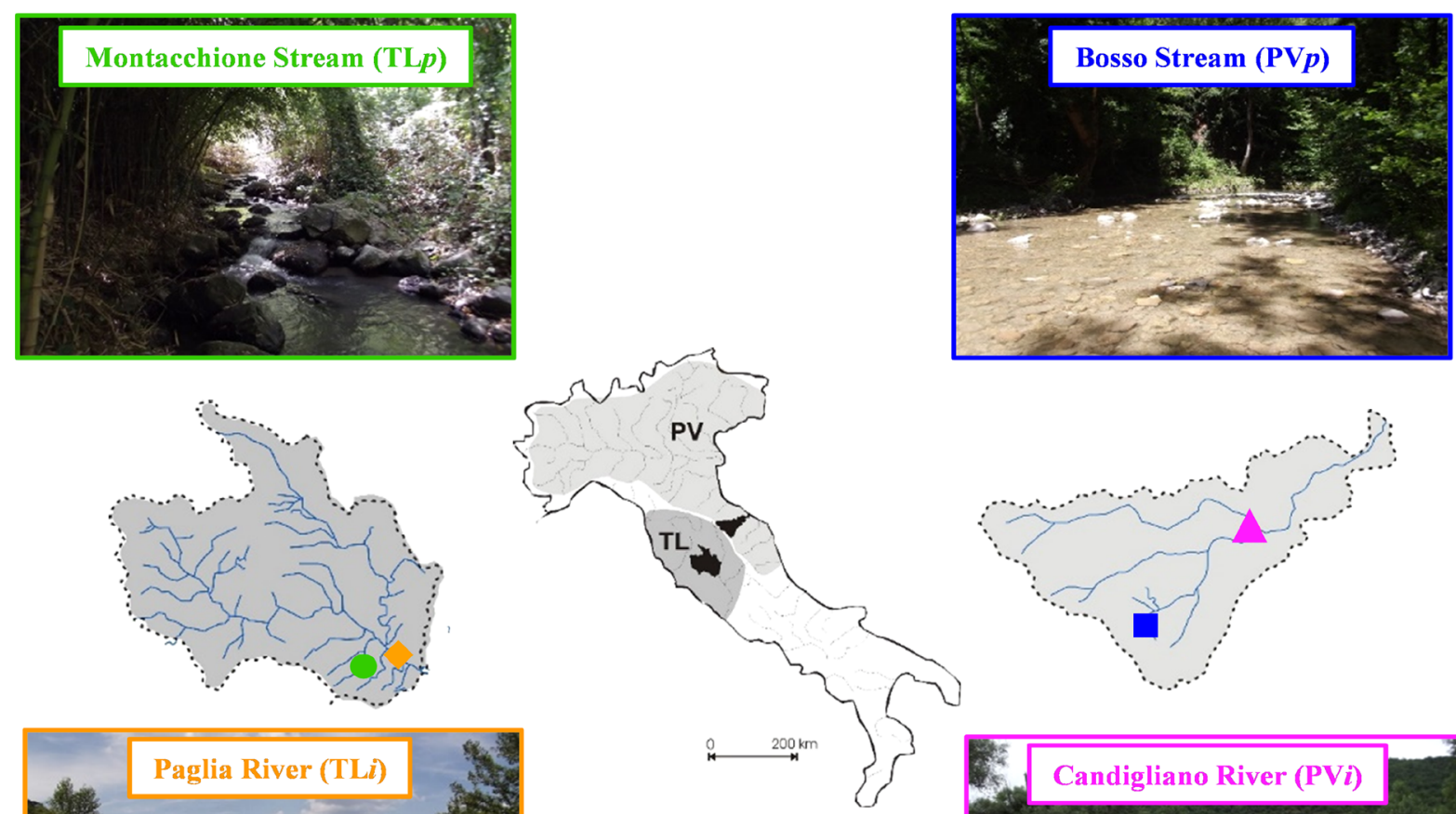
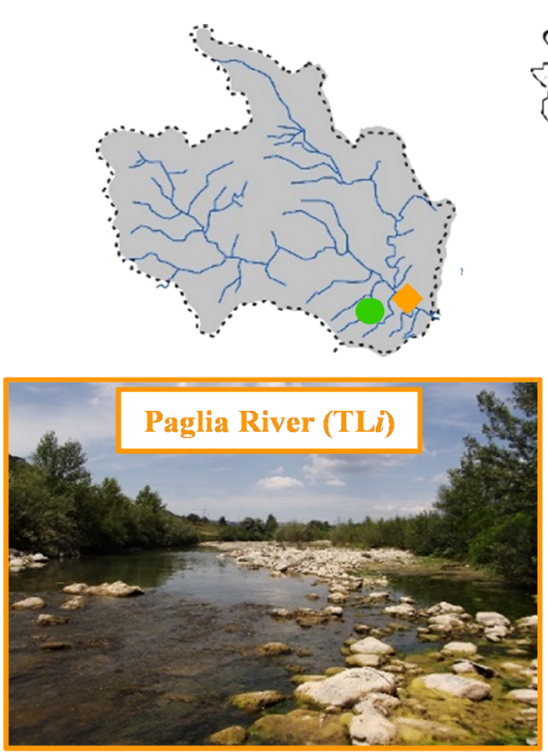

Fig. 1 Location and pictures of the four sampled rivers located within the Tuscany-Latium (TL) and the Padano-Venetian districts (PV) where ' $i$ ' and ' $p$ ' indicate sites where hybrid and purebred populations were found. Symbols on maps indicate position of each site where: $\mathrm{PV} p=$ blue square, $\mathrm{PV} i=$ pink triangle, $\mathrm{TL} p=$ green circle and $\mathrm{TL} i=$ orange diamond 
Table 1 Habitat characteristics of the four sampling sites and community metrics for macroinvertebrate and fish diversity at each site with relative geographic coordinates, ichthyogeographic district, basin, river and site identification code

\begin{tabular}{|c|c|c|c|c|}
\hline \multirow{2}{*}{$\begin{array}{l}\text { Ichthyogeographic district } \\
\text { Basin }\end{array}$} & \multicolumn{2}{|c|}{ Padano-Venetian (PV) } & \multicolumn{2}{|c|}{ Tuscany-Latium (TL) } \\
\hline & Metauro & Metauro & Tiber & Tiber \\
\hline River & Bosso & Candigliano & Montacchione & Paglia \\
\hline Site ID & $\mathrm{PV} p$ & $\mathrm{PV} i$ & TLp & $\mathrm{TL} i$ \\
\hline Geographic coordinates & $\begin{array}{l}43^{\circ} 31^{\prime} 3.14^{\prime \prime N} \\
12^{\circ} 33^{\prime} 17.89^{\prime \prime} \mathrm{E}\end{array}$ & $\begin{array}{l}43^{\circ} 38^{\prime} 8.59^{\prime \prime N} \\
12^{\circ} 42^{\prime} 41.32^{\prime} \mathrm{E}\end{array}$ & $\begin{array}{r}42^{\circ} 42^{\prime} 44.39^{\prime \prime N} \\
12^{\circ} 5^{\prime} 37.88^{\prime \prime} \mathrm{E}\end{array}$ & $\begin{array}{r}42^{\circ} 43^{\prime} 38.88^{\prime \prime N} \mathrm{~N} \\
12^{\circ} 7^{\prime} 43.00 ” \mathrm{E}\end{array}$ \\
\hline \multicolumn{5}{|l|}{ Habitat characteristics } \\
\hline Distance from source $(\mathrm{Km})$ & 10 & 41 & 10 & 57 \\
\hline Altitude (m a.m.s.l) & 398 & 201 & 207 & 116 \\
\hline River width (m) & 7 & 16 & 5 & 17 \\
\hline Canopy cover $(\%)$ & 90 & 10 & 90 & 10 \\
\hline Geology & Siliceous & Siliceous & Volcanic & Siliceous \\
\hline \multicolumn{5}{|l|}{ Substrate composition (\%) } \\
\hline $\begin{array}{l}\text { Microlithal (grain size } \\
2-6 \mathrm{~cm} \text { ) }\end{array}$ & 30 & 60 & 0 & 20 \\
\hline $\begin{array}{l}\text { Mesolithal (grain size } \\
6-20 \mathrm{~cm} \text { ) }\end{array}$ & 40 & 40 & 20 & 40 \\
\hline $\begin{array}{l}\text { Macrolithal (grain size } \\
20-40 \mathrm{~cm} \text { ) }\end{array}$ & 30 & 0 & 40 & 40 \\
\hline $\begin{array}{l}\text { Megalithal (grain } \\
\text { size }>40 \mathrm{~cm})\end{array}$ & 0 & 0 & 40 & 0 \\
\hline \multicolumn{5}{|l|}{ Mesohabitat typology (\%) } \\
\hline Riffle & 20 & 30 & 15 & 70 \\
\hline Rapid & 10 & 5 & 10 & 5 \\
\hline Step & 10 & 5 & 30 & 0 \\
\hline Run & 40 & 45 & 15 & 10 \\
\hline Pool & 20 & 15 & 30 & 5 \\
\hline \multicolumn{5}{|c|}{ Macroinvertebrate community metrics } \\
\hline $\begin{array}{l}\text { Total density (individuals/ } \\
\mathrm{m}^{2} \text { ) }\end{array}$ & 1094 & 5662 & 1212 & 848 \\
\hline Family richness & 24 & 19 & 15 & 17 \\
\hline $\begin{array}{l}\text { Shannon-Wiener diversity } \\
(\mathrm{H})\end{array}$ & 2.0 & 1.5 & 1.6 & 1.5 \\
\hline \multicolumn{5}{|l|}{ Fish community metrics } \\
\hline $\begin{array}{l}\text { Total density (individuals/ } \\
\mathrm{m}^{2} \text { ) }\end{array}$ & 3.40 & 1.97 & 0.78 & 8.27 \\
\hline Species richness & 6 & 8 & 5 & 8 \\
\hline $\begin{array}{l}\text { Shannon-Wiener diversity } \\
(\mathrm{H})\end{array}$ & 0.5 & 1.4 & 0.9 & 0.5 \\
\hline
\end{tabular}

upstream section), and one invaded and introgressed (" $i$ ") population (in the lowland section). Pure vs. hybrid status of populations have already been tested using mitochondrial (D-loop) and nuclear (growth hormone 2; GH-2) DNA markers (see Zaccara et al.
2020). Thus, PVp and TLp were known to be populated by purebred $B$. plebejus and B. tyberinus respectively. Mitochondrial DNA analyses had revealed that barbel in PV $i$ and TL $i$ were all of hybrid origin (B. plebejus $\times$ B. barbus and B. tyberinus $\times B$. 
barbus, respectively), while at the analysed nuclear marker, a different proportion of B. barbus alleles was detected between the two invaded populations, resulting in a higher number of $B$. barbus alleles in TLi $(81 \%)$ than PVi $(68 \%)$ (Zaccara et al. 2020).

Sites in TL were situated within the Paglia River basin and were the Paglia River (TLi) and the Montacchione Stream (TLp) (Fig. 1; Table 1), where the latter is a tributary isolated from the main river by the presence of two weirs of over $2 \mathrm{~m}$ high. This basin is characterized by impermeable soils, with watercourses flowing in upland areas (Lorenzoni et al. 2010). Sites in PV were located within the Metauro River basin, being the Candigliano River (PVi) and the Bosso Stream (PVp) (Fig. 1); these sites were separated by three weirs, ranging in height from 0.4 to $1 \mathrm{~m}$. This basin has a mountainous upper section that cuts across an area of steeply folded bedrock (Lorenzoni and Esposito 2011).

All of these watercourses were characterised by marked flow rate oscillations throughout the year and a high susceptibility to drought periods in summer, which are aggravated by water abstraction for irrigation and drinking water supply. The Montacchione sub-basin has a volcanic origin, while the other three are siliceous. Downstream sites (i.e. TL $i$ and PV $i$ ) were characterised by a wider riverbed than the upstream sites, which results in major vegetation cover of the latter that provides shading even during summer droughts. Substrates at all sites were characterised by coarse material, primarily boulders and cobbles in varying percentages, which were mainly mesolithal $(6-20 \mathrm{~cm})$ and macrolithal $(20-40 \mathrm{~cm})$. Mesohabitats at all sites were mainly characterised by riffle-run hydro-morphologies, except for TL $p$ that was dominated by a step-pool hydro-morphology (Table 1; Fig. 1).

Fish and macroinvertebrate communities sampling and characterisation

Quantitative sampling of the fish communities was completed in July 2019 by electrofishing using DC electric current $(2500 \mathrm{~W})$. To estimate fish density, a two-pass electrofishing approach was implemented (Moran 1951; Zippin 1956), involving the survey of a longitudinal transect of length 60 to $112 \mathrm{~m}$ (according to river size) in a downstream-upstream direction, applying the same sampling effort twice. Although no stop nets were used, the end of the transects were determined by river morphology (e.g. a significant reduction of riverbed width (i.e. mesohabitat change) or a weir). The sampling was conducted between 10 am and $12 \mathrm{pm}$ in each river; following their capture, the fish were anaesthetised, identified to species where possible (including non-Barbus species), measured for total length (to $1 \mathrm{~mm}$ ) and weight (to $0.1 \mathrm{~g}$ ).

A quantitative multi-habitat approach (Buffagni et al. 2005) was then used to sample benthic macroinvertebrate (BMI) communities using a Surber sampler $\left(0.1 \mathrm{~m}^{2}\right.$ area, $500 \mu \mathrm{m}$ mesh). Once collected, BMI samples were preserved in formalin $(4 \%)$ and, then, in the laboratory, were sorted into families whose density (individuals $/ \mathrm{m}^{2}$ ) was determined by counting individuals. For each sampling site, the fish and BMI assemblages were characterised through the calculation of three common metrics: total density (i.e. number of individuals per $\mathrm{m}^{2}$ ), richness (fish: number of species; BMI: number of families) and diversity (Shannon-Wiener index - H; Shannon 1948). The Bray-Curtis index (Bray and Curtis 1957) was used to quantify the compositional dissimilarity between BMI samples, where values ranged from 0 (completely similar) and 1 (completely dissimilar). These analyses were performed with the Past software (Hammer et al. 2001).

Barbel biological traits

After their measurement, three to five scales were removed from each barbel, taken from the left side, that were used subsequently for age determination. Scalimetry was performed under a stereomicroscope coupled with a camera, with images stored within an archive built with the image analysis system IAS 2000 (QEA's IASLab® software). Two operators carried out ageing of scales from the images independently, discarding unreadable or dubious scales. Length at age relationships of each population were then fitted to the von Bertalanffy growth model (von Bertalanffy 1938) according to:

$\mathrm{TL}=\mathrm{L}_{\infty}\left(1-\exp \left(-\mathrm{K}\left(\mathrm{t}-\mathrm{t}_{0}\right)\right)\right)$

Where TL is the total length of each fish in $\mathrm{mm}$ at time $\mathrm{t}, \mathrm{L}_{\infty}$ is the theoretical maximum length, $\mathrm{K}$ is the rate of approach to the maximum length, and $t_{0}$ is the theoretical age at which $\mathrm{TL}=0$. To assess possible differences in theoretical growth parameters between 
populations, different non-linear models were fitted using von Bertalanffy equation in the fisheries assessment R package 'FSA' (Ogle et al. 2020; R core team 2019) following a hierarchical approach (Ogle 2013). This consisted in starting with a general model in which $\mathrm{L}_{\infty}, \mathrm{K}$ and $\mathrm{t}_{0}$ were calculated for each population independently and subsequently simplifying the model by keeping constant initially one and then two parameters at a time, finishing with a model where all the three parameters were in common. The best-fit model was then selected according to the Akaike's information criterion (AIC; Burnham and Anderson 1998). Differences in length-at-age between populations were tested through MANOVA in $\mathrm{R}$ ('dplyr' package, Wickham et al. 2020), with age and length kept as dependent variables and sampling site retained as independent variable.

Length-weight relations (LWRs) in each population was also estimated using the following linear regression model:

$\log _{10} \mathrm{~W}=\mathrm{a}+\operatorname{blog}_{10} \mathrm{TL}$

Where $\mathrm{W}$ is the weight in grams of the fish, TL is the total length in $\mathrm{mm}, a$ is the intercept of the regression curve and $b$ is the regression coefficient (slope). ANCOVA was used to test for differences in LWR across the populations, with differences from isometric growth (i.e. $b=3$ ) tested for each population using $t$-tests. LWR models obtained for each population were then used to back calculate fish weight, and residuals (differences between observed and predicted weight) were tested for significant differences (one way ANOVA) in fish body condition between the populations (Jakob et al. 1996).

Barbel diet determination through gut content analysis (GCA)

A subsample of barbel (approximately 20 fish per site of age $>1+$ and up to $4+$, and lengths between 69 and $279 \mathrm{~mm}$ ) were selected for gut content analysis (GCA). These fish were euthanized (anaesthetic overdose, MS-222), placed on ice and brought to the laboratory. After their defrosting, the fish were dissected, and their guts preserved in ethanol $(70 \%)$ prior to analysis. As barbels do not have a differentiated stomach, the entire digestive tract ('gut') was weighed and all the prey items examined using microscopy (x 5 to x 50 magnification). Prey were initially identified to the lowest possible taxonomic level before being grouped into 15 categories according to their taxonomic affinities. Food items with a low frequency, low specific abundances $(<5 \%)$ and/or that occurred in only one population, were grouped into broader categories (i.e. terrestrial organisms, other aquatic BMI, fish bones). As the actions of the pharyngeal teeth of barbels makes the separation of their ingested prey difficult, this prevented the effective use of gravimetric or numeric methods and, consequently, the relative-fullness method was selected (Hyslop 1980). This method is recommended as one of the election methods in relative diet composition studies, as it can produce robust data despite its subjective nature (Amundsen and SánchezHernández 2019). Accordingly, gut fullness was estimated on a scale from empty $(0 \%)$ to full $(100 \%)$, with the volumetric percentage of each food item then estimated by eye and summed up to reach the total fullness. The feeding activity of the fish in each population was then tested comparing the vacuity index (I \%; calculated as the proportion of fish with empty stomachs in each sample; Hyslop 1980, Alexandre et al. 2015) and the mean volume of gut contents. To ensure the barbel subsample used for GCA was representative of the diet variation of each fish population, prey accumulation curves were constructed using a sample-based rarefaction method as available in the 'BiodiversityR' package in R (Kindt and Coe 2005).

The fish feeding strategy was then assessed following the method proposed by Costello (1990) in its modified version (Amundsen et al. 1996), where the frequency of occurrence and prey-specific abundances of each food category are calculated and used to plot graphs. Visual inspection of the plots indicates prey importance, feeding strategy and, ultimately, how each individual contributes to the trophic niche of the population by specialising on specific dietary items (i.e. within phenotypic contribution) or not (i.e. between phenotypic contribution). Correspondingly, the frequency of occurrence of each food category for each population was calculated as the percentage of fish with prey $i$ in their guts against the total number of fish with contents in their guts $\left(F_{i} \%=N_{i} / N \times 100\right)$. Prey-specific abundances were calculated as the volume occupied by prey item $i\left(S_{i}\right)$ in all the guts against the total gut volume comprising prey $i\left(P_{i} \%=\right.$ $\sum S_{i} / \sum S_{t i}$ x 100; Amundsen et al. 1996). 
The GCA data were then analysed for diet composition and niche width area per population. Data were arcsine square root transformed and non-metric multidimensional scaling (nMDS) was performed with $40 \%$ standard ellipses representing the core population trophic niche (Gutmann Roberts and Britton 2018), as implemented in the $\mathrm{R}$ package 'vegan' (Oksanen et al. 2019). A Bray-Curtis distance matrix was built before PERMANOVA ('adonis' function) was used to test for dietary differences between the four populations. SIMPER analysis was then applied to detect the contribution of each food item to the dissimilarities. The Shannon-Wiener diversity index (H) was also calculated within the same package (i.e. vegan), and ANOVA and Tukey pairwise test available in $\mathrm{R}$ tested for differences in $\mathrm{H}$ between the four populations.

Stable isotope analysis (SIA) of barbel populations and putative food resources

For the stable isotope analyses (SIA), the fish used differed to those used in the GCA but were collected concomitantly. This was partly due to logistical reasons related to both sample collection and to the Covid-19 lockdown that prevented the fish from the GCA being analysed in a timely manner for the purposes of this study. Consequently, 10 barbel per site were analysed for SIA $\left(\delta^{13} \mathrm{C}\right.$ and $\left.\delta^{15} \mathrm{~N}\right)$. All individuals analysed were of age between $1+$ and $4+$ years old and of lengths between 98 and $244 \mathrm{~mm}$. Scales were used as the tissue of choice for SIA as they represent non-lethal alternatives to muscles (Busst et al. 2015; Busst and Britton 2018) and are indicative of diet composition over considerable timeframes (> 3 months for B. barbus; Busst and Britton 2018). Three to five scales were removed from the left side (above the lateral line and below the dorsal fin) and then placed in paper envelopes until processing.

To provide SIA data for the baselines and putative prey, BMI, biofilm (periphyton), benthic algae and fine and coarse particular organic matter (FPOM and CPOM respectively) were sampled on the same date of the fish. A dedicated BMI sample was collected at each site with the same method used to characterize the BMI communities, but this was put on ice and frozen upon arrival in the laboratory. After defrosting, six families (Baetidae, Chironomidae, Gammaridae (only in TLp), Hydropsychidae, Leuctridae (except
TL $p$ ), Simuliidae (except TLi)) that were mostly present at all sampling sites were selected (Supplementary material Table S1) and three replicates of each family (comprising of 1 up to 10 individuals, according to the size) were processed. These families mainly comprised a mix of collector gatherers, grazers and scrapers, but also included shredders, filter feeders and predators (www.freshwaterecology.info; Schmidt-Kloiber and Hering 2015). Biofilm was brushed from the upper side of six stones randomly picked up at each sampling site and then combined in $500 \mathrm{ml}$ of water. Samples were frozen until processing in the laboratory, where each sample was divided in three replicates and filtered on glass-fibre filters $(0.7 \mu \mathrm{m}$ pore size). Two litres of turbid water were collected moving fine substrate with hands for FPOM collection, and then three replicates were filtered on glassfibre filters. CPOM (mainly decaying leaves) and benthic algae (except for TL $p$ ) were randomly collected by hand at each sampling site and combined to form three replicates.

Preparation for SIA of fish scales, BMI and benthic algae involved rinsing with distilled water before being oven dried at $60{ }^{\circ} \mathrm{C}$ for $48 \mathrm{~h}$, with this drying also performed for the biofilm, FPOM and CPOM samples. For the scales, a preliminary step was added that involved the excision of the outer portion of each scale for analysis, as this reflects the collagen produced in the last growth season and not in previous life stages (Hutchinson and Trueman 2006). The stable isotope ratios of carbon $\left({ }^{13} \mathrm{C}:{ }^{12} \mathrm{C}\right.$; reported as $\left.\delta^{13} \mathrm{C}\right)$ and nitrogen $\left({ }^{15} \mathrm{~N}:{ }^{14} \mathrm{~N}\right.$, reported as $\left.\delta^{15} \mathrm{~N}\right)$ of the fish, putative prey and baseline samples were then analysed at the Cornell Isotope Laboratory, New York (USA). Across the four sites, 142 samples were analysed: 40 fish, 57 BMI (five families per site) and 45 primary producers (Supplementary material Table S1). Samples were ground to powder, weighed (to the nearest $1000 \mu \mathrm{g}$ ) and put in tin capsules, before being analysed on a Thermo delta $\mathrm{V}$ isotope mass spectrometer (IRMS) coupled with a NC2500 elemental analyser. Data accuracy and precision were tested every 10 samples reporting an overall standard deviation for internal animal standard (deer) of 0.08 for $\delta^{15} \mathrm{~N}$ and 0.03 for $\delta^{13} \mathrm{C}$. The $\mathrm{C}: \mathrm{N}$ ratios of all animal samples were below 3.5 and so did not require lipid correction (Skinner et al. 2016).

The SIA data were initially tested for any effects of length on $\delta^{13} \mathrm{C}$ and $\delta^{15} \mathrm{~N}$ (as a proxy of ontogenetic 
effects on diet) in each population through linear regressions as implemented in R. A Bayesian approach available in the R package 'tRophicPosition' (Quezada-Romegialli et al. 2018) was then implemented to calculate trophic position (TP) at population level and to test for differences in TP between the purebred and hybrid populations. Since the samples for SIA were collected in one season, some of the putative prey, specifically primary producers, may not be reflective of the stable isotope ratios of the fish because of different turnover rates. This, coupled with the fact that barbel are mainly invertivores, led to the use of BMI as the baselines, since they would integrate isotopes on a temporal scale similar to that of the fish (Post et al. 2002). However, as the analysed BMI were not always distinguishable from each other based on their stable isotope ratios (i.e. their standard deviation overlapped; Supplementary material Table S1), then these resources were pooled, resulting in one baseline model being implemented. The trophic discrimination factor used for $\delta^{15} \mathrm{~N}$ (i.e. $\Delta^{15} \mathrm{~N}$ ) was $4.2 \% \pm 0.2 \%$, with this specific to scales for $B$. barbus, derived experimentally from individuals that had fed on an invertebrate-based diet (Busst and Britton 2016). The probability that the posterior distribution relative to each population's TP was higher or smaller than others ( $\alpha=0.05$ ) was used to test for significant differences.

To enable individual comparisons between the different rivers, barbel $\delta^{15} \mathrm{~N}$ ratio was converted to TP according to Olsson et al. (2009):

$$
\mathrm{TP}=2+\delta^{15} \mathrm{~N}_{\text {barbel }}-\delta^{15} \mathrm{~N}_{\text {meanBMI }} / 4.2
$$

Where TP and $\delta^{15} \mathrm{~N}_{\text {barbel }}$ are the trophic position and the nitrogen ratio of each fish and $\delta^{15} \mathrm{~N}_{\text {meanBMI }}$ is the mean nitrogen ratio of the benthic macroinvertebrates and 2 is the trophic position of this latter (i.e. primary consumers). Although it is recommended to estimate consumer TPs through the use of baseline taxa that are long-lived (e.g. bivalves and snails) (Post 2002), there were insufficient densities of these taxa in the samples to enable this. Similarly, for Barbus $\delta^{13} \mathrm{C}$, conversions to corrected carbon $\left(\mathrm{C}_{\text {corr }}\right)$ utilised the $\delta^{13} \mathrm{C}$ data of the BMI using the following equation (adapted from Olsson et al. 2009):

$$
\mathrm{C}_{\text {corr }}=\left[\left(\delta^{13} \mathrm{C}_{\text {barbel }}-\Delta^{13} \mathrm{C}\right)-\delta^{13} \mathrm{C}_{\text {meanBMI }}\right] / \mathrm{CR}_{\mathrm{BMI}}
$$

Wherein $\delta^{13} \mathrm{C}_{\text {barbel }}$ is the carbon value of each fish, $\Delta{ }^{13} \mathrm{C}$ is carbon tissue-specific trophic discrimination factor for B. barbus fed an invertebrate diet (Busst and Britton 2016), $\delta^{13} \mathrm{C}_{\text {meanBMI }}$ is the mean carbon ratio of all the benthic macroinvertebrates sampled for SIA and $\mathrm{CR}_{\mathrm{BMI}}$ is the carbon range $\left(\delta^{13} \mathrm{Cmax}-\delta^{13} \mathrm{Cmin}\right)$ of the same macroinvertebrates (Olsson et al. 2009). ANOVA implemented in $\mathrm{R}$ was used to test for differences in carbon source between populations.

The isotopic niches of each population were then built using two approaches in the SIBER R package (Jackson et al. 2011), the maximum likelihood Standard Ellipse Area (SEA) and the Bayesian estimate of the SEA $\left(\mathrm{SEA}_{\mathrm{B}}\right)$. SEA $\mathrm{S}_{\mathrm{B}}$ was tested for significant differences in niche width between populations and obtained through Markov Chain Monte Carlo simulations $\left(10^{4}\right.$ iterations per group), with differences calculated as the probability that the posterior distribution relative to each population niche was larger or smaller than others $(\alpha=0.05)$. Maximum likelihood estimate of SEAs were used to plot the niches in the isotopic space, where they represent the population 'core' niche (40\%), and enabled identification of the extent of isotopic niche overlap between the different barbel populations (Jackson et al. 2012).

\section{Results}

Characterization of fish and benthic macroinvertebrate communities

The fish communities of the four sites differed considerably in terms of composition, density and richness (Table 1; Supplementary material Table S2). At PVp, the dominant species were Telestes muticellus (Bonaparte 1837) and Cottus gobio Linnaeus 1758; at PVi, Gobio gobio (Linnaeus 1758) was most abundant; at TL $p$ it was Barbus tyberinus; and at TL $i$ it was Padogobius nigricans (Canestrini 1867). These taxa are all native, except for G. gobio at PVi. At PV $i$, three of eight fish species present were alien and at TL $i$, five of eight were alien (Table S2). All fish species at $\mathrm{PV} p$ and TL $p$ were native, except for two salmonid species (Atlantic lineage of Salmo trutta Linnaeus 1758 and Oncorhyinchus mykiss Walbaum 1792, 
respectively). At TL $i$ there was the highest density of fishes followed by $\mathrm{PV} p$, with both sites having a relatively lower diversity than the other two sites (Table 1).

Similarly, the composition of the BMI communities varied between the four sampling sites (Supplementary material Table S3), with values of the Bray-Curtis index ranging from 0.54 (PVp vs. TLi) to 0.96 (TL $p v s$. $\mathrm{PV} i$ ). The TL $p$ community differed the most from the other communities (Bray-Curtis index $>0.87$ ) and was dominated by the gastropods Lymnaeidae and Planorobidae (Table S3). At PV $i$, there was the highest BMI density while the lowest was in TL $p$ (Table 1). At $\mathrm{PV} p$ BMI community was relatively more diverse and richer than at the other sites (Table 1).

\section{Barbel age structure and condition}

Across the four populations, seven age classes $(0+$ to $6+)$ were present at fish lengths of 38 to $286 \mathrm{~mm}$. Fish of $5+$ and $6+$ years were only present in the purebred barbel populations (TL $p$ and $\mathrm{PV} p$ ), with fish in the introgressed populations reaching a maximum age of $3+(\mathrm{TL} i)$ and 4+ (PVi) years (Fig. 2a). The most frequent age classes present were $1+$ in hybrid populations and $2+$ in purebred populations. As the length data were not homogeneously distributed in terms of number of individuals per age class, theoretical growth model calculations were performed on the mean total lengths, where data on the age $5+$ and $6+$ fish were not included as they were not present in all the populations. The model in which $\mathrm{L}_{\infty}$ and $\mathrm{t}_{0}$ varied across the populations while $\mathrm{K}$ remained constant $\quad(\mathrm{K}=0.24 \pm 0.03$ standard error $)$ was selected as the best-fitting model, indicating that the introgressed barbel (both at TL $i$ and PV $i$ ) had significantly larger maximum theoretical lengths than purebreds (Table 2). MANOVA indicated significantly different length-at-age between sites for age classes from $1+$ to $4+$ (Pillai's trace $=0.5 ; \mathrm{F}_{2,245}=$ 31.67, $p<0.001$ ), with hybrids having greater mean lengths at ages equal and/or greater than 2 years old (Fig. 2b).

Length-weight relations (LWRs) varied significantly across the populations (ANCOVA: $\mathrm{F}_{3}, 293=$ $1430, p<0.001)$ and within each population, LWR models were highly significant $\left(\mathrm{R}^{2} \geq 0.96\right.$, $p<0.001$; Table 2). Allometric negative growth (i.e. $b<3$; t-test $p<0.05$ ) was detected in all
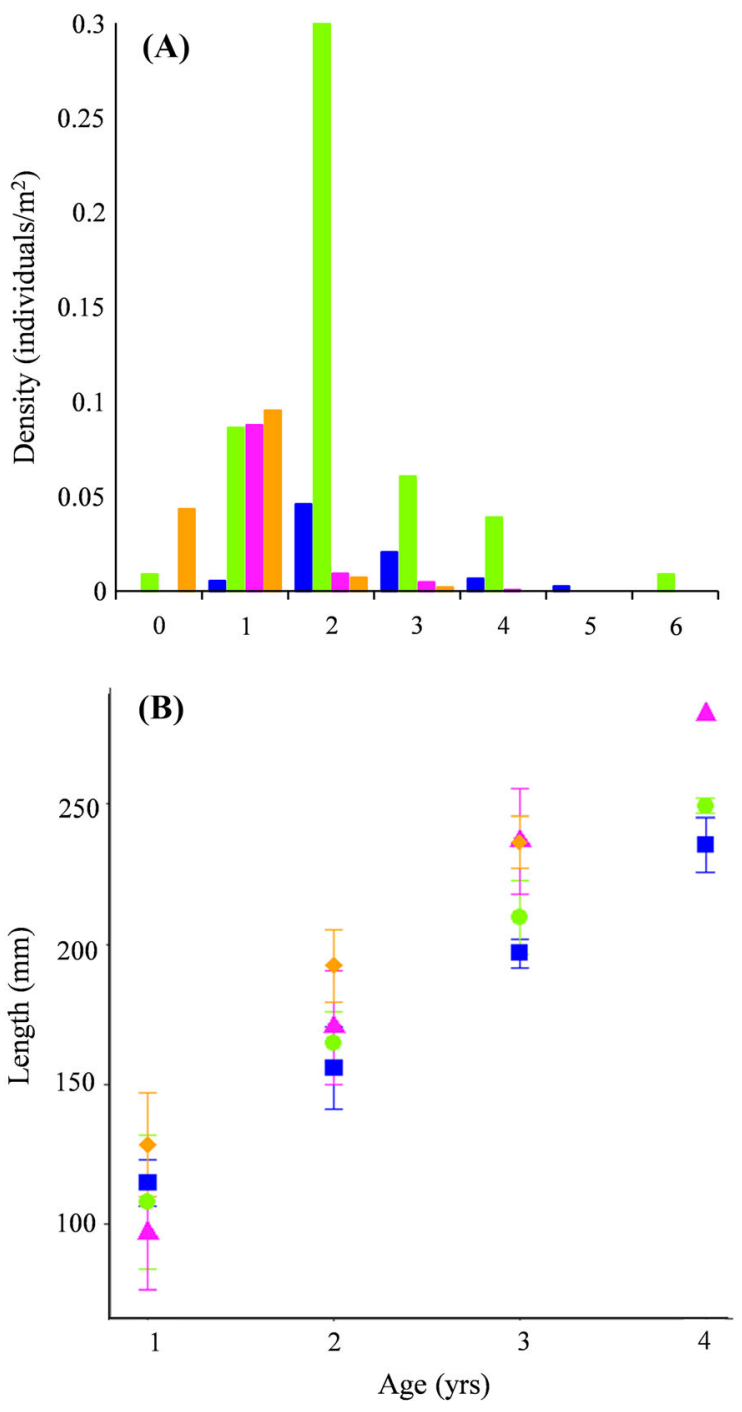

Fig. 2 (a) Age class structure of barbel at each site where bars indicate density (individuals $\left./ \mathrm{m}^{2}\right)$ for each age class $(0+$ to $6+)$ of fish sampled at PVp, TL $p, \operatorname{PV} i$ and TL $i$ respectively. (b) Mean total lengths ( \pm standard deviations) of barbel of ages $1+$ to $4+$ sampled at $\mathrm{PV} i$ (pink triangles), TL $i$ (orange diamonds), $\mathrm{PV} p$ (blue squares) and TL $p$ (green circles) sites

populations except for TLp $(b=3.0)$. Conversely, body condition indices were all around zero (Table 2) and did not vary between barbel populations (ANOVA $\left.\mathrm{F}_{3,294}=1.35 ; p>0.05\right)$.

Barbel diet composition and dietary niche

The fish analysed for GCA were not significantly different in length across the rivers (ANOVA: $\mathrm{F}_{3,77}=$ 
Table 2 Mean \pm standard error of length-weight relation (LWR) parameters with relative body index (BI), maximum theoretical lengths $\left(\mathrm{L}_{\infty}\right)$ and theoretical age at which the total length of the fish is equal to $0\left(\mathrm{t}_{0}\right)$ calculated by the best-fitting von Bertalanffy (1938) model for introgressed (PV $i$ and TL $i$ ) and purebred populations (PVp and TL $p$ )

\begin{tabular}{llllllll}
\hline Population & $\mathrm{N}$ & \multicolumn{2}{l}{ LWR parameters } & & & \\
\cline { 2 - 8 } & & $a$ & $b$ & $\mathrm{R}^{2}$ & $\mathrm{BI}$ & $\mathrm{L}_{\infty}$ & $\mathrm{t}_{0}$ \\
\hline $\mathrm{PV} p$ & 41 & $0.015 \pm 0.19$ & $2.83 \pm 0.07$ & 0.98 & $0.01 \pm 0.01$ & $34.4 \pm 1.8$ & $-0.60 \pm 0.10$ \\
$\mathrm{PV} i$ & 72 & $0.016 \pm 0.17$ & $2.78 \pm 0.07$ & 0.96 & $0.01 \pm 0.03$ & $45.7 \pm 3.1$ & $0.03 \pm 0.07$ \\
$\mathrm{TL} p$ & 44 & $0.011 \pm 0.10$ & $2.99 \pm 0.04$ & 0.99 & $0.01 \pm 0.01$ & $35.9 \pm 1.7$ & $-0.50 \pm 0.10$ \\
$\mathrm{TL} i$ & 141 & $0.014 \pm 0.07$ & $2.80 \pm 0.03$ & 0.99 & $0.01 \pm 0.02$ & $41.1 \pm 2.8$ & $-0.55 \pm 0.10$ \\
\hline
\end{tabular}

The rate of approach to $L_{\infty}$ remained constant $(K=0.24 \pm 0.03)$ between the populations and it is not reported in the table. $\mathrm{N}=$ number of barbel analysed per population; $a=$ intercept of the LWR regression curve, $b=$ regression coefficient (slope), $\mathrm{R}^{2}=$ determination coefficient of the LWR regression curve

$0.84 ; p>0.05)$. The proportion of fish with empty guts (vacuity index, I \%) ranged between $0 \%$ (TLp) to $21 \%$ (TLi) (Table 3), with mean gut fullness being the highest and the lowest in the same rivers respectively (ANOVA: $\mathrm{F}_{3,69}=14.86 ; p<0.001$ ). Prey accumulation curves were approaching the asymptote in all populations, suggesting the subsample of gut analysed was sufficient to represent the diet variability of barbel populations (Supplementary material Figure S1). The most frequent food items in barbel diets across all sites were aquatic insect larvae, particularly Chironomidae (Supplementary material Figure S2 and Table S4). Feeding strategy plots (Figure S2) indicated generalized feeding behaviour in all populations, with all barbel frequently consuming certain prey items (e.g. Chironomidae and Simuliidae), but with some differences in the contributions of others (e.g. Mollusca, terrestrial organisms and plants). However, an exception was in TLi and PVi, where there was some dietary specialization through some individuals feeding on fish (Figure S2). This resulted in considerable differences in diet composition among sites, with significant differences in the population trophic niches (PERMANOVA test: $\mathrm{F}_{3}, 69=14.75, R^{2}=0.40$; $p<0.001)$. The widest trophic niche was in TLi and then PVp (as shown by $40 \%$ ellipses in the nMDS analysis, Table 3; Fig. 3 A). All pairwise comparisons revealed significant differences in niche composition between the populations ( $\left.p_{\text {adj }}<0.01\right)$, with the highest overall average dissimilarity in the diet of TLi barbels ( $\geq 75.6 \%$; Table S4). The diet of hybrids in TLi lacked the items that were frequent and abundant in the diets of the other populations (e.g. Mollusca, Hydropsychidae and other Trichoptera), while consuming food categories (e.g. fish bones and plants) that were absent or infrequent in the other populations (Table S4 and Figure S1). The diet of barbel at TL $i$ was also the most distant from the macroinvertebrate community present at the site of capture as shown by the nMDS analysis (Fig. 3a). Although there were significant differences in $\mathrm{H}$ between the diets of the barbel populations (ANOVA: $\mathrm{F}_{3}, 69=11.76$; $p<0.001$ ), pairwise comparisons indicated these

Table 3 Mean vacuity index (I \%) and mean percent gut fullness, Shannon-Wiener diversity index of diet $(\mathrm{H})$ and dietary niche width estimated as $40 \%$ nMDS ellipse area for purebred (TL $p$ and PVp) and hybrid (TL $i$ and PV $i$ ) barbel populations

\begin{tabular}{lllllll}
\hline Population & N & TL (range) & I \% & Mean gut fullness (\%) & H & Niche nMDS \\
\hline PV $p$ & 20 & $155(110-252)$ & 10 & $62 \pm 25$ & $1.35 \pm 0.50$ & 0.26 \\
PV $i$ & 20 & $160(72-279)$ & 10 & $60 \pm 28$ & $1.37 \pm 0.34$ & 0.14 \\
TL $p$ & 22 & $180(91-285)$ & 0 & $85 \pm 14$ & $1.69 \pm 0.24$ & 0.21 \\
TL $i$ & 19 & $159(69-241)$ & 21 & $32 \pm 27$ & $0.89 \pm 0.52$ & 0.90 \\
\hline
\end{tabular}

Number of fish analysed for GCA per population (N), mean total length (TL) and relative range (mm) are also given 


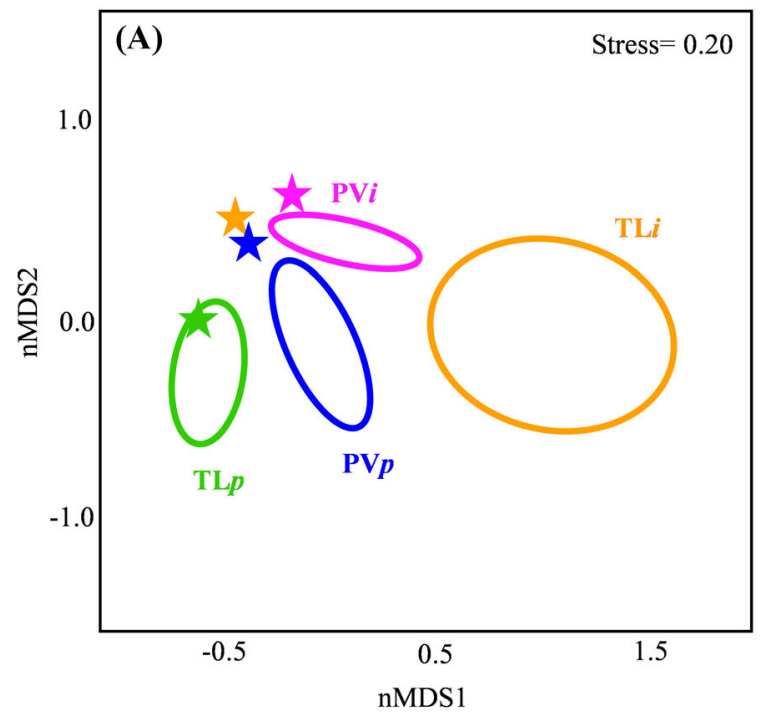

Fig. 3 a Non-metric multidimensional scaling (nMDS) graph showing the dietary niches built as standard ellipses enclosing $40 \%$ of the gut content data within each population and macroinvertebrate community composition at each site as indicated by colored star symbols. b Isotopic niches of each

were only significant between TLi and the other sites (Tukey test, $p_{\text {adj }}<0.001$ ) (Table 3).

Stable isotopes, barbel trophic position and isotopic niches

Across the four sites, $\delta^{13} \mathrm{C}$ BMI varied, with the carbon range being between $1.6 \%$ (TL $i$ ) and $6.1 \%$ $\left(\mathrm{PV} p\right.$ ) (Fig. 4; Table S1). FPOM was particularly ${ }^{13} \mathrm{C}$ enriched in all rivers except for TLp (Table S1). Values of $\delta^{15} \mathrm{~N}$ were more similar for both BMI and primary producers between TL $p$ and PV $i$ (Fig. 4, Table S1), while there was an enrichment of ${ }^{15} \mathrm{~N}$ at TLi. In the barbel populations, there was no evidence of significant ontogenetic shifts in $\delta^{15} \mathrm{~N}$ and $\delta^{13} \mathrm{C}$ (Supplementary material Table S5), except for fish in $\mathrm{PV} p$ where $\delta^{13} \mathrm{C}$ decreased as fish length increased (Table S5). There was no significant difference in the length of the fish analysed between rivers $\left(F_{3,36}=\right.$ $0.15, p>0.05$ ).

A significantly lower trophic position (as indicated by posterior probability distributions) was detected for barbel in TL $i$ compared to TP in the other populations (TP 2.4 vs. $>2.8$; Table 4). No significant differences were found in $\mathrm{C}_{\text {corr }}$ between rivers $\left(\mathrm{F}_{3,36}=0.84\right.$,

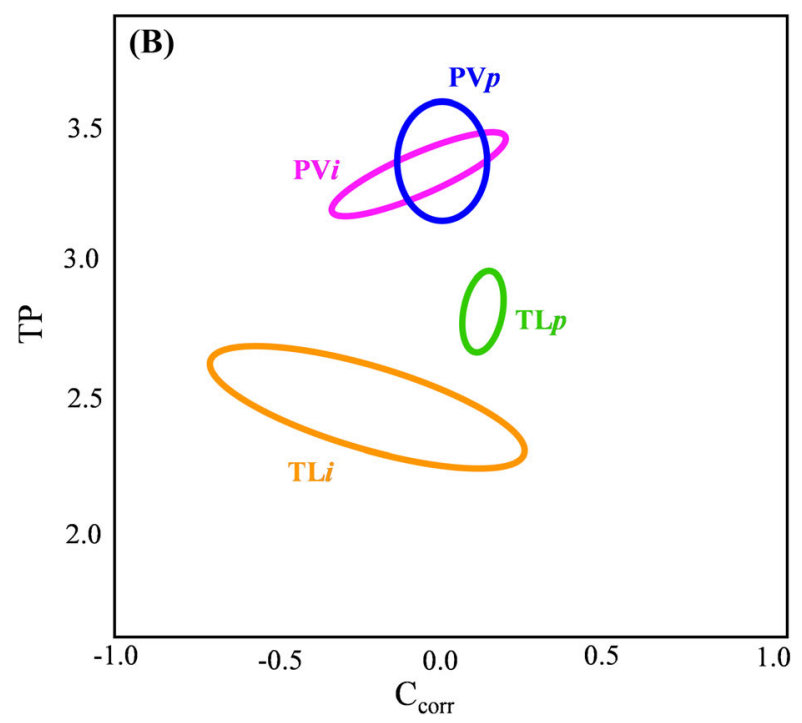

barbel population built on the corrected stable isotope data as maximum likelihood standard ellipse area (SEA) enclosing $40 \%$ of the data for introgressed (PVi $i=$ pink and TL $i=$ orange) and purebred $(\mathrm{PV} p=$ blue and $\mathrm{TL} p=$ green $)$ barbel populations

$p>0,05)$ and length was subsequently removed due to its non-significant effect $(p>0.05)$. The isotopic niche size of the barbel was significantly larger in TL $i$ and smaller in TL $p$ (as indicated by posterior distributions of the core isotopic niche as $\mathrm{SEA}_{\mathrm{B}}$ ), with the niches being similarly sized in $\mathrm{PV} p$ and $\mathrm{PV} i$ (Table 4). In general, the positions of these niches in the isotopic space did not overlap except for $\mathrm{PV} p$ and $\mathrm{PV} i$ that shared $6 \%$ of their core niches (Fig. 3b).

\section{Discussion}

The testing of the ecological and biological consequences of introgressive hybridisation of the endemic $B$. tyberinus and B. plebejus following B. barbus invasion revealed substantial changes in some biological traits of introgressed populations and an altered trophic ecology in one of the hybrid population. These results reveal important insight into the ecology of the hybridized progenies and highlight the potential impacts of hybridization at wider ecosystem scales.

The growth characteristics of the hybrids (B. barbus $\times$ B. tyberinus and B. barbus $\times$ B. plebejus), including their maximum theoretical lengths and lengths at age, 


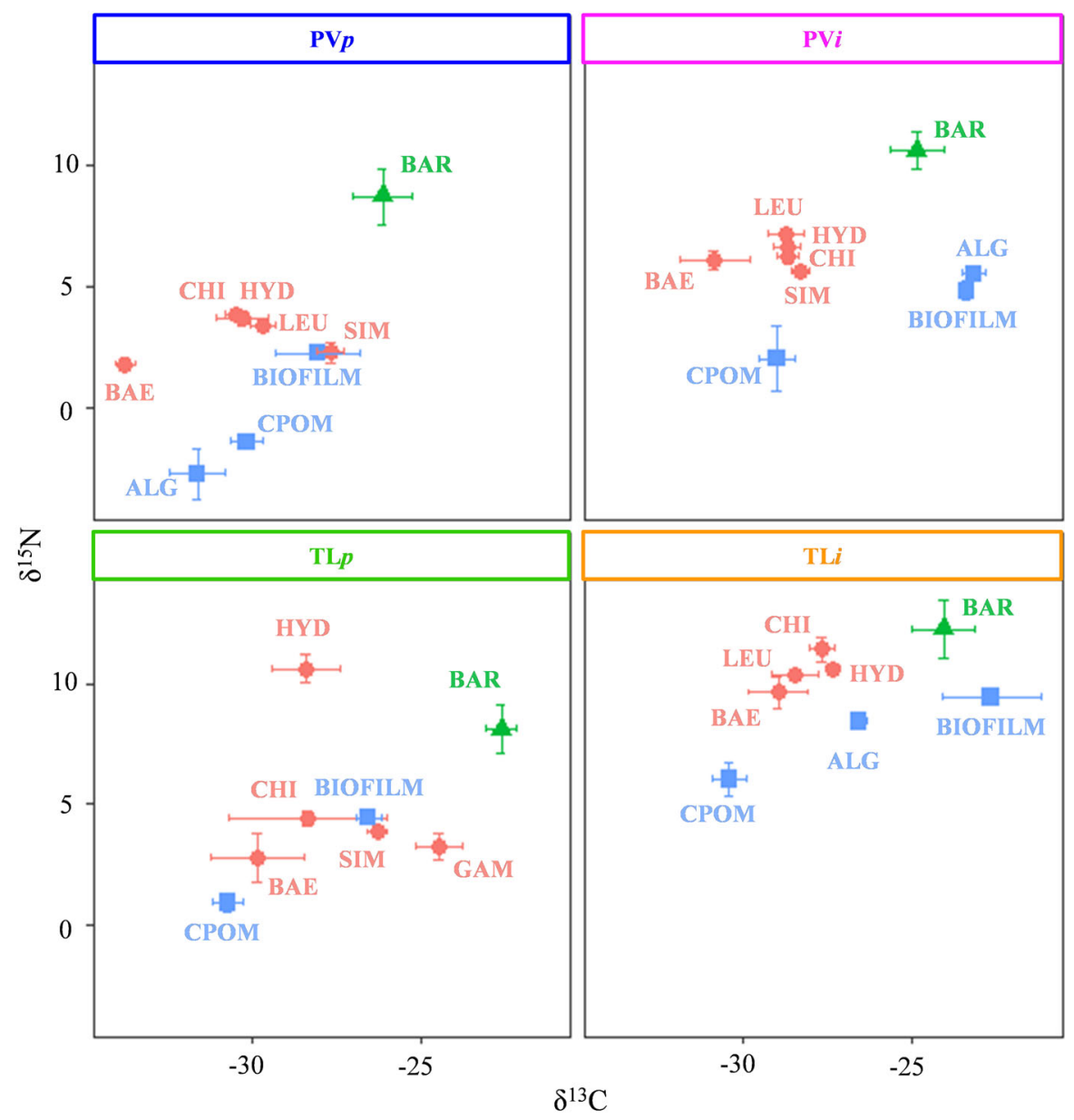

Fig. 4 Stable isotope mean ratios with standard deviations (bars) of barbel (green triangles), macroinvertebrates (pink circles) and primary producers (blue squares) collected at four sites. $\mathrm{BAR}=$ barbel; macroinvertebrates: $\mathrm{BAE}=$ Baetidae, $\mathrm{CHI}=$ Chironomidae, $\mathrm{HYD}=$ Hydropsychidae, $\mathrm{GAM}=\mathrm{Gam}-$ maridae,$\quad \mathrm{LEU}=$ Leuctridae,$\quad \mathrm{SIM}=$ Simuliidae; primary

Table 4 Mean bulk stable isotope ratio \pm standard deviation, Bayesian estimate of trophic position (TP) with relative $95 \%$ credible intervals and corrected carbon values

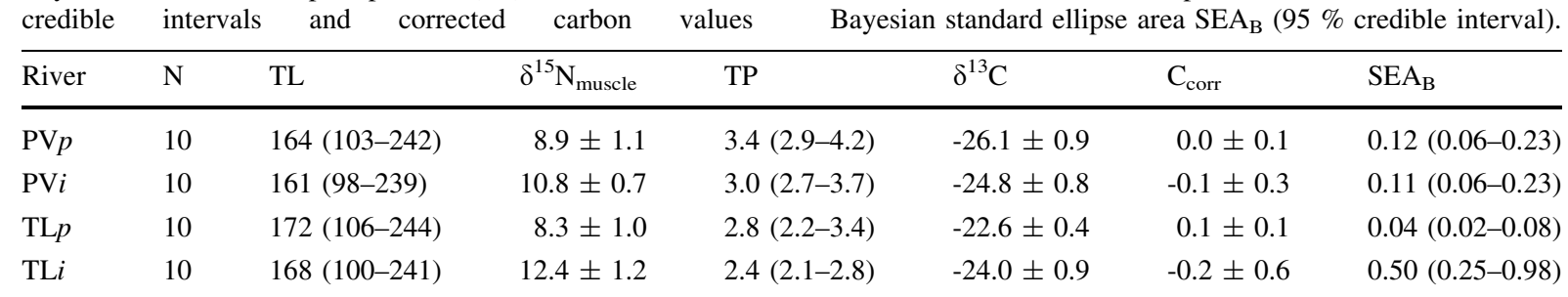

Number of samples analysed (N) and mean total length (TL) in $\mathrm{mm}$ and relative range (in brackets) are provided producers: $\quad \mathrm{CPOM}=$ coarse particulate organic matter, ALG = benthic algae. FPOM was omitted from the graph as it was particularly depleted in ${ }^{13} \mathrm{C}$ in almost all the sites (except $\mathrm{PV} p$ ) compared to barbel and BMI and therefore not useful as baseline (cf. Table S1)

$\left(\mathrm{C}_{\text {corr }}\right) \pm$ standard deviation of each barbel population together with estimation of the isotopic niche breath calculated as Bayesian standard ellipse area SEA SE $_{\text {( }} \%$ credible interval) 
were higher in the invaded populations than in the purebred populations, as per the prediction. These results are also similar to those from previous studies on B. barbus hybrid populations of central (Carosi et al. 2017) and northern Italy (Meraner et al. 2013), and suggest an element of hybrid vigour. Indeed, similar patterns of hybrid vigour have been recorded in other interbreeding fish species, such as Cyprinodon pecosensis Echelle \& Echelle 1978 and its congener $C$. variegatus Lacepède 1803 (Rosenfield et al. 2004), the Japanese strain of Cyprinus carpio Linnaeus 1758 and its domestic exotic lineage (Matsuzaki et al. 2010), and Abramis brama (Linnaeus 1758) and Rutilus rutilus (Linnaeus 1758) (Toscano et al. 2010; Hayden et al. 2011). Moreover, hybrid vigour has been documented in a range of other animal and plant species (Burke and Arnold 2001; Pfennig et al. 2007; Hovick and Whitney 2014). The increased size of barbel hybrids may enhance recruitment through a higher number of eggs being spawned (Philippart and Berrebi 1990; Meraner et al. 2013; Gutmann Roberts et al. 2020) compared to the smaller native purebreds. This, along with the related vigour of the introgressed progenies, potentially helps to explain the rapid expansion of hybridization in invaded population by B. barbus. Alternatively, the larger size of alien barbel and its hybrids may play an active role in sexual selection, with larger females being more attractive to barbel males than the smaller native females (Meraner et al. 2013).

The second prediction concerned the differences in trophic ecology between hybrids and purebred barbel populations and were tested using a combination of gut contents (GCA) and stable isotope (SIA) analyses. These techniques are considered to be largely complementary (e.g. Nolan and Britton 2018) and are often used together in fish trophic studies (e.g. Locke et al. 2013; Hamidan et al. 2016), although they do reflect two different aspects of animals' feeding ecology that can result in discordant outcomes (e.g. Pacioglu et al. 2019). Where GCA represents a dietary snapshot of an individual in real time, representing the prey consumed in the preceding hours, SI data integrate spatial and temporal dietary components over a period of days to months, depending on the actual tissue analysed (Vander Zanden et al. 2015). Here, scale material was used that, in B. barbus, has a relatively slow isotopic turnover rate compared to other tissues (Busst and Britton 2018), thus the temporal aspect of the diet being indicated was likely to be over 3 months. Despite these core methodological differences, the two methods were consistent in demonstrating some considerable differences in the diet composition and trophic niche of the TLi hybrid population compared to their reference parental population (TL $p$ ), and, conversely, only minor differences between the $\mathrm{PV} i$ hybrid population and its reference purebred population $(\mathrm{PV} p)$. The introgressed barbel of TL $i$ differed to the other three populations studied in their relatively high proportions of small fishes and plants in their diet, which resulted in a relatively low trophic position. The diets of the other populations were all dominated by benthic macroinvertebrate prey. These differences were then reflected in their trophic niche size, with the hybrids in TLi having the broadest isotopic and trophic niches.

The relatively high proportion of prey fishes in the diet of the introgressed barbel of TL $i$ aligns to some $B$. barbus populations having diets in which prey fishes are present, albeit usually in low frequencies (Piria et al. 2005; Gutmann Roberts et al. 2017). Recreational anglers also frequently capture larger individuals on baits comprising of high proportions of marine fishmeal, suggesting that fish prey are attractive to adult $B$. barbus (De Santis et al. 2019). The barbel of TL $i$ were the only population here where small benthic fishes were detected at relatively high frequency in diet by GCA, despite considerable overlap in the body sizes present, and the presence of small benthic fishes in all sites. The diet of the TLi hybrid barbel had the lowest diversity (in terms of the Shannon-Wiener index) of all populations, but as these fish had both plant and fish material present then they actually had the widest trophic niche. Moreover, TL $i$ site had the highest fish density and a lower macroinvertebrate density than PV $i$ site, so these data suggest that the hybrids of TL $i$ preyed upon smaller fish through the combination of their high availability and relatively lower availability of macroinvertebrate resources, a pattern that was not evident elsewhere (Supplementary material Table S2 and S3). We can thus speculate that the hybrids in TLi were primarily consuming common food resources in the site rather than preferentially selecting small fishes as dietary items. However, it highlights both their diet plasticity and a shift in their functional feeding guild (Noble et al. 2007) from primarily being insectivorous (Oberdoff et al. 1993; Piria et al. 2005; Corse et al. 2010) in other 
sites to being omnivorous in TLi. This functional shift is potentially important in the context of assessments of their ecological impact (Cucherousset and Olden 2011).

In terms of their age structure and growth, the hybrid populations were relatively similar, despite their trophic differences. These results are consistent with morphological analyses that were conducted on the same populations (Zaccara et al. 2020), where the TLi barbel showed a marked morphological differentiation from the purebred B. tyberinus in their body shape, whereas the hybrids of PV $i$ resulted relatively similar to the morphology of the PVp barbel phenotype. In general, these hybrid populations were characterised by individuals with deeper bodies and larger caudal fins than in the purebred ones, which displayed body-shapes that were potentially better adapted to fast flowing waters and unsteady swimming mode (Meyers and Belk 2014). This then could partly explain the difference in the trophic ecology observed in this study, as the functional morphology of fish is an important driver of their diet (Klingenberg et al. 2003) through its influence on their foraging mode and efficiency of prey capture (Webb 1984).

Different habitat conditions and interspecific competition may have been responsible for some of the observed trophic shift of hybrids in TLi population. For example, differences in canopy cover, such those present between upstream (PV $p$ and TL $p$ ) and downstream (PV $i$ and TL $i$ ) sites, could have influenced the trophic strategy shift and niche broadening of fish in TLi (e.g. De Carvalho et al. 2019). Nevertheless, this was not apparent in the hybrid population of PVi, despite similar habitat conditions (i.e. canopy cover, river geomorphology, river width, altitude and distance from source; Table 1) thus suggesting that environmental parameters were unlikely to have been important in driving this trophic response. Interspecific competition with other fishes could also have influenced the trophic ecology of the studied hybrids. Indeed, the highest fish density was in TLi, in large part caused by the high density of the Arno goby $P$. nigricans (Table S2), an invertivore (Pompei et al. 2014). However, experimental studies have shown decreased trophic niche sizes in relation to interspecific competition in B. barbus and other cyprinids (Britton et al. 2019; De Santis et al. 2021), which contrasts with the findings of this study. Specialization and subsequent reduction in trophic niche breadth have also facilitated the coexistence between other omnivorous fishes when resources are limited (e.g. Neves et al. 2021). Therefore, by the effect of interspecific competition, we mightmight have expected the trophic niche of TLi population to be more restricted. Variation in the trophic ecology of different hybrid classes (i.e. differences in the extent of introgression) has been detected in hybrids between native Japanese Cyprinus carpio lineages and nonnative strains (Matsuzaki et al. 2010). Invasion history (e.g. time since the first introduction), propagule pressure, habitat structure and disturbance are all factors that may contribute to the different genotypic composition of hybrid populations (Hayden et al. 2011; Corse et al. 2015). Thus, future studies may involve a higher number of populations representative of different habitat conditions and populations with different genotypic structure to verify to which extent the pattern observed in this study are driven by changes in the genotype and phenotype, versus those driven by differences in their environment, including in prey availability and interspecific competition (Corse et al. 2015).

In summary, the results here provide evidence of an ecological shift in one barbel population introgressed with the invader $B$. barbus. In this population, the morphological change in the hybrids was associated to their exploitation of different prey resources, although the extent to which this was also driven by differences in prey availability and habitat condition was unable to be tested. In both the introgressed populations studied, hybrids grew to considerably larger sizes and had larger lengths at age, suggesting a potential reproductive advantage compared to purebred fish. These results highlight, for the first time, that $B$. barbus invasion not only results in the introgression with congeners with consequent genetic pollution, but these introgressed fish may then interact quite differently within the receiving communities than their nonhybridised parents. Although the role of other factors could not be verified, these results support the hypothesis that invasive hybridisation is, potentially, a major driver of ecological change.

Acknowledgements The authors thank the fisheries departments for the local authorization to promote research activities in the field. We thank Prof. Chris Harrod and Dr Pietro Volta for their valuable suggestions in previous revisions of this manuscript and anonymous reviewers for their indications. 
Funding Open access funding provided by Università degli Studi dell'Insubria within the CRUI-CARE Agreement. VDS and SQ were supported by grants from University of Insubria

Availability of data and material All data produced in this study are available upon requests from the corresponding author;

Code availability All codes used in this study are available upon requests from the corresponding author.

\section{Declarations}

Conflict of interest The authors declare no conflict of interests nor competing interests.

Consent to participate All persons entitled to authorship have been so named and have agreed to participate.

Consent for publication All authors have seen and agreed to the submitted version of the manuscript.

Ethical approval Sampling protocols were established in compliance with the ethical standards, ensuring that all necessary precautions, required by Italian legislation, have been taken and the welfare of the fish has been respected.

Open Access This article is licensed under a Creative Commons Attribution 4.0 International License, which permits use, sharing, adaptation, distribution and reproduction in any medium or format, as long as you give appropriate credit to the original author(s) and the source, provide a link to the Creative Commons licence, and indicate if changes were made. The images or other third party material in this article are included in the article's Creative Commons licence, unless indicated otherwise in a credit line to the material. If material is not included in the article's Creative Commons licence and your intended use is not permitted by statutory regulation or exceeds the permitted use, you will need to obtain permission directly from the copyright holder. To view a copy of this licence, visit http://creativecommons.org/licenses/by/4.0/.

\section{References}

Alexandre CM, Sales S, Ferreira MT, Almeida PR (2015) Food resources and cyprinid diet in permanent and temporary Mediterranean rivers with natural and regulated flow. Ecol Freshw Fish 24:629-645

Allendorf FW, Leary RF, Spruell P, Wenburg JK (2001) The problems with hybrids: setting conservation guidelines. Trends Ecol Evol 16:613-622

Amundsen PA, Gabler HM, Staldvik FJ (1996) A new approach to graphical analysis of feeding strategy from stomach contents data-modification of the Costello (1990) method. J Fish Biol 48:607-614

Amundsen P, Sánchez-Hernández J (2019) Feeding studies take guts - critical review and recommendations of methods for stomach contents analysis in fish. J Fish Biol 95:1364-1373

Baack EJ, Rieseberg LH (2007) A genomic view of introgression and hybrid speciation. Curr Opin Genet Dev 17:513-518

Bianco PG (1995) Mediterranean endemic freshwater fishes of Italy. Biol Conserv 72:159-170

Bianco PG, Ketmaier V (2001) Anthropogenic changes in the freshwater fish fauna of Italy, with reference to the central region and Barbus graellsii, a newly established alien species of Iberian origin. J Fish Biol 59:190-208

Bray JR, Curtis JT (1957) An ordination of the upland forest communities of southern Wisconsin. Ecol Monogr 27:326-349

Brennan AC, Woodward G, Seehausen O, Muñoz-Fuentes V, Moritz C, Guelmami A, Abbott RJ, Edelaar P (2014) Hybridization due to changing species distributions: adding problems or solutions to conservation of biodiversity during global change? Evol Ecol Res 16:475-491

Britton JR, Pegg J (2011) Ecology of European barbel Barbus barbus: implications for river, fishery, and conservation management. Rev Fish Sci 19:321-330

Britton JR, Gutmann Roberts C, Amat Trigo F, Nolan ET, De Santis V (2019) Predicting the ecological impacts of an alien invader: experimental approaches reveal the trophic consequences of competition. J Anim Ecol 88:1066-1078

Buonerba L, Zaccara S, Delmastro GB, Lorenzoni M, Salzburger W, Gante HF (2015) Intrinsic and extrinsic factors act at different spatial and temporal scales to shape population structure, distribution and speciation in Italian Barbus (Osteichthyes: Cyprinidae). Mol Phylogenetics Evol 89:115-129

Buffagni A, Erba S, Ciampittiello M (2005) Il rilevamento idromorfologico e degli habitat fluviali nel contesto della Direttiva Europea sulle Acque (WFD): principi e schede di applicazione del metodo Caravaggio. IRSA-CNR Notiziario dei Metodi Analitici 2:32-46. (Italian)

Burke JM, Arnold ML (2001) Genetics and the fitness of hybrids. Annu Rev Genet 35:31-52

Burnham KP, Anderson DR (1998) Model selection and inference: an information-theoretic approach. Springer, New York

Busst GMA, Bašić T, Britton JR (2015) Stable isotope signatures and trophic-step fractionation factors of fish tissues collected as non-lethal surrogates of dorsal muscle: nonlethal tissue surrogates for fish isotope studies. Rapid Commun Mass Spectrom 29:1535-1544

Busst GMA, Britton JR (2016) High variability in stable isotope diet-tissue discrimination factors of two omnivorous freshwater fishes in controlled ex situ conditions. J Exp Biol 219:1060-1068. doi:https://doi.org/10.1242/jeb. 137380

Busst GMA, Britton JR (2018) Tissue-specific turnover rates of the nitrogen stable isotope as functions of time and growth in a cyprinid fish. Hydrobiologia 805:49-60

Carosi A, Ghetti L, La Porta G, Lorenzoni M (2017) Ecological effects of the European barbel Barbus barbus (L., 1758) (Cyprinidae) invasion on native barbel populations in the Tiber River basin (Italy). Eur Zool J 84:420-435 
Chafin TK, Douglas MR, Martin BT, Douglas ME (2019) Hybridization drives genetic erosion in sympatric desert fishes of western North America. Heredity 123:759-773

Corse E, Costedoat C, Chappaz R, Pech N, Martin JF, Gilles A (2010) A PCR-based method for diet analysis in freshwater organisms using 18S rDNA barcoding on faeces. Mol Ecol Res 10:96-108. doi:https://doi.org/10.1111/j.1755-0998. 2009.02795.x

Corse E, Pech N, Sinama M, Costedoat C, Chappaz R, Gilles A (2015) When anthropogenic river disturbance decreases hybridisation between non-native and endemic cyprinids and drives an ecomorphological displacement towards juvenile state in both species. Plos One 10:e0142592

Costello MJ (1990) Predator feeding strategy and prey importance: a new graphical analysis. J Fish Biol 36:261-263

Cucherousset J, Olden JD (2011) Ecological impacts of nonnative freshwater fishes. Fisheries 36:215-230

Davis AM, Blanchette ML, Pusey BJ, Jardine TD, Pearson RG (2012) Gut content and stable isotope analyses provide complementary understanding of ontogenetic dietary shifts and trophic relationships among fishes in a tropical river: isotopic ecology of some tropical fishes. Freshw Biol 57:2156-2172

De Carvalho DR, de Castro DMP, Callisto M, de Moura Chaves AJ, Moreira MZ, Pompeu PS (2019) Stable isotopes and stomach content analyses indicate omnivorous habits and opportunistic feeding behaviour of an invasive fish. Aquat Ecol 53:365-381

De Santis V, Gutmann Roberts C, Britton JR (2019) Influences of angler subsidies on the trophic ecology of European barbel Barbus barbus. Fish Res 214:35-44

De Santis V, Gutmann Roberts C, Britton JR (2021) Trophic consequences of competitive interactions in freshwater fish: density dependent effects and impacts of inter-specific versus intra-specific competition. Freshw Biol 66:362-373

Gaskin JF, Kazmer DJ (2009) Introgression between invasive saltcedars (Tamarix chinensis and T. ramosissima) in the USA. Biol Invasions 11:1121-1130

Geiger MF, Schreiner C, Delmastro GB, Herder F (2016) Combining geometric morphometrics with molecular genetics to investigate a putative hybrid complex: a case study with barbels Barbus spp. (Teleostei: Cyprinidae): a hybrid complex of Italian Barbus spp. J Fish Biol 88:1038-1055

Gutmann Roberts C, Bašić T, Britton JR, Rice S, Pledger AG (2020) Quantifying the habitat and zoogeomorphic capabilities of spawning European barbel Barbus barbus, a lithophilous cyprinid. River Res Applic 36:259-279. https://doi.org/10.1002/rra.3573

Gutmann Roberts C, Britton JR (2018) Quantifying trophic interactions and niche sizes of juvenile fishes in an invaded riverine cyprinid fish community. Ecol Freshw Fish 27:976-987

Hänfling B, Bolton P, Harley M, Carvalho GR (2005) A molecular approach to detect hybridisation between crucian carp (Carassius carassius) and non-indigenous carp species (Carassius spp. and Cyprinus carpio). Freshw Biol 50:403-417. https://doi.org/10.1111/j.1365-2427.2004. 01330.x
Hamidan N, Jackson MC, Britton JR (2016) Diet and trophic niche of the endangered fish Garra ghorensis in three Jordanian populations. Ecol Freshw Fish 25:455-464

Hammer $\check{R}$, Harper DAT, Ryan PD (2001) PAST: Paleontological statistics software package for education and data analysis. Palaeontol Electron 4:9

Hayden B, Massa-Gallucci A, Caffrey J, Harrod C, Mariani S, O'Grady M, Kelly-Quinn M (2011) Trophic dynamics within a hybrid zone - interactions between an abundant cyprinid hybrid and sympatric parental species. Freshw Biol 56:1723-1735

Hovick SM, Whitney KD (2014) Hybridisation is associated with increased fecundity and size in invasive taxa: metaanalytic support for the hybridisation-invasion hypothesis. Ecol Lett 17:1464-1477

Hutchinson JJ, Trueman CN (2006) Stable isotope analyses of collagen in fish scales: limitations set by scale architecture. J Fish Biol 69:1874-1880

Huxel GR (1999) Rapid displacement of native species by invasive species: effects of hybridization. Biol Conserv 89:143-152

Hyslop EJ (1980) Stomach contents analysis-a review of methods and their application. J Fish Biol 17:411-429

Jackson AL, Inger R, Parnell AC, Bearhop S (2011) Comparing isotopic niche widths among and within communities: SIBER - Stable Isotope Bayesian Ellipses in R: Bayesian isotopic niche metrics. J Anim Ecol 80:595-602

Jackson MC, Donohue I, Jackson AL, Britton JR, Harper DM, Grey J (2012) Population-level metrics of trophic structure based on stable isotopes and their application to invasion ecology. Plos One 7:e31757

Jakob EM, Marshall SD, Uetz GW (1996) Estimating fitness: a comparison of body condition indices. Oikos 77:61

Kindt R, Coe R (2005) Tree diversity analysis: a manual and software for common statistical methods for ecological and biodiversity studies. World Agroforestry Centre (ICRAF), Nairobi (Kenya). ISBN 92-9059-179-X, http://www. worldagroforestry.org/output/tree-diversity-analysis

Klingenberg CP, Barluenga M, Meyer A (2003) Body shape variation in cichlid fishes of the Amphilophus citrinellus species complex: body shape variation in Amphilophus citrinellus. Biol J Linn Soc Lond 80:397-408

Kovach RP, Muhlfeld CC, Boyer MC, Lowe WH, Allendorf FW, Luikart G (2015) Dispersal and selection mediate hybridization between a native and invasive species. Proc Royal Soc B 282:20142454

Locke SA, Bulte G, Forbes MR, Marcogliese DJ (2013) Estimating diet in individual pumpkinseed sunfish Lepomis gibbosus using stomach contents, stable isotopes and parasites. J Fish Biol 82:522-537

Lorenzoni M, Esposito L (2011) La Carta Ittica delle Marche. Regione Marche, Assessorato Caccia e Pesca Sportiva, Ancona

Lorenzoni M, Ghetti L, Carosi A, Dolciami R (2010) La fauna ittica e i corsi d'acqua dell'Umbria. Sintesi delle carte ittiche regionali dal 1986 al 2009. Petruzzi Editore, Perugia

Matsuzaki SS, Mabuchi K, Takamura N, Hicks BJ, Nishida M, Washitani I (2010) Stable isotope and molecular analyses indicate that hybridization with non-native domesticated common carp influence habitat use of native carp. Oikos 119:964-971 
Meraner A, Venturi A, Ficetola GF, Rossi S, Candiotto A, Gandolfi A (2013) Massive invasion of exotic Barbus barbus and introgressive hybridization with endemic Barbus plebejus in Northern Italy: where, how and why? Mol Ecol 22:5295-5312

Meyers PJ, Belk MC (2014) Shape variation in a benthic stream fish across flow regimes. Hydrobiologia 738:147-154

Moran PAP (1951) A mathematical theory of animal trapping. Biometrika 38:307-311

Neves MP, Kratina P, Delariva RL, Jones JI, Fialho CB (2021) Seasonal feeding plasticity can facilitate coexistence of dominant omnivores in neotropical streams. Rev Fish Biol Fisheries 31:1-16

Noble RAA, Cowx IG, Goffaux D, Kestemont P (2007) Assessing the health of European rivers using functional ecological guilds of fish communities: standardising species classification and approaches to metric selection. Fish Manag Ecol 14:381-392

Nolan ET, Britton JR (2018) Diet of invasive pikeperch Sander lucioperca: developing non-destructive tissue sampling for stable isotope analysis with comparisons to stomach contents analysis. Knowl Manag Aquat Ecosyst 419:49

Oberdorff T, Guilbert E, Lucchetta JC (1993) Patterns of fish species richness in the Seine River basin, France. Hydrobiologia 259:157-167

Olsson K, Stenroth P, Nyström P, Granéli W (2009) Invasions and niche width: does niche width of an introduced crayfish differ from a native crayfish? Freshw Biol 54:1731-1740

Oksanen J, Blanchet FG, Friendly M, Kindt R, Legendre P, McGlinn D, Minchin PR, O'Hara RB, Simpson GL, Solymos P, Stevens MHH, Szoecs E, Wagner H (2019) Vegan: Community Ecology Package. R package version 2.5-6. https://CRAN.R-project.org/package=vegan

Ogle DH (2013) fishR Vignette: Length-weight relationships, http://derekogle.com/fishR/examples/oldFishRVignettes/ LengthWeight.pdf

Ogle DH, Wheeler P, Dinno A (2020) FSA: Fisheries Stock Analysis. R package version 0.8.31, https://github.com/ droglenc/FSA

Pacioglu O, Zubrod JP, Schulz R, Jones JI, Pârvulescu L (2019) Two is better than one: combining gut content and stable isotope analyses to infer trophic interactions between native and invasive species. Hydrobiologia 839:25-35

Pfennig KS, Chunco AJ, Lackey ACR (2007) Ecological selection and hybrid fitness: hybrids succeed on parental resources. Evol Ecol Res 9:341-354

Philippart JC, Berrebi P (1990) Expiremental hybridation of Barbus barbus and Barbus meridionalis: physiological, morphological, and genetic aspects. Aquat Living Resour 3:325-332

Piria M, Treer T, Aničić I, Safner R, Odak T (2005) The natural diet of five cyprinid fish species. Agric Conspec Sci 70:21-28

Pompei L, Giannetto D, Lorenzoni M (2014) Feeding ecology of Padogobius nigricans (Canestrini, 1867) and P. bonelli (Bonaparte, 1846) in Aggia River (Umbria, Italy) and their diet overlap. Hydrobiologia 740:101-113

Post DM (2002) Using stable isotopes to estimate trophic position: models, methods, and assumptions. Ecology 83:703-718
Quezada-Romegialli C, Jackson AL, Hayden B, Kahilainen KK, Lopes C, Harrod C (2018) tRophicPosition, an R package for the Bayesian estimation of trophic position from consumer stable isotope ratios. Methods Ecol Evol 9:1592-1599

R Core Team (2019) R: A language and environment for statistical computing. R Foundation for Statistical Computing, Vienna, Austria. URL https://www.R-project.org/

Rhymer JM, Simberloff D (1996) Extinction by hybridization and introgression. Annu Rev Ecol Syst 27:83-109

Rieseberg LH, Whitton J, Gardner K (1999) Hybrid zones and the genetic architecture of a barrier to gene flow between two sunflower species. Genetics 152:713-727

Rosenfield JA, Nolasco S, Lindauer S, Sandoval C, KodricBrown A (2004) The role of hybrid vigor in the replacement of pecos pupfish by its hybrids with sheepshead minnow: genetic homogenization of endemic pupfish. Conserv Biol 18:1589-1598

Roy D, Lucek K, Walter RP, Seehausen O (2015) Hybrid 'superswarm' leads to rapid divergence and establishment of populations during a biological invasion. Mol Ecol 24:5394-5411

Schmidt-Kloiber A, Hering D (2015) www.freshwaterecology.info - an online tool that unifies, standardises and codifies more than 20,000 European freshwater organisms and their ecological preferences. Ecol Indic 53:271-282. https://doi.org/10.1016/j.ecolind.2015.02.007

Seehausen O (2004) Hybridization and adaptive radiation. Trends Ecol Evol 19:198-207

Shannon CE (1948) A mathematical theory of communication. Bell Syst Tech J 27:379-423

Skinner MM, Martin AA, Moore BC (2016) Is lipid correction necessary in the stable isotope analysis of fish tissues? Rapid Commun Mass Spectrom 30:881-889

Svardal H, Quah FX, Malinsky M, Ngatunga BP, Miska EA, Salzburger W, Genner MJ, Turner GF, Durbin R (2019) Ancestral hybridisation facilitated species diversification in the Lake Malawi cichlid fish adaptive radiation. Evol Biol, https://doi.org/biorxiv.org/lookup/doi/10.1101/ 738633

Tancioni L, Baldari F, Ferrante I, Scardi M, Mancini L (2001) Feeding habits of some native and introduced fish species in the low stretch or Tiber River (central Italy). Ente tutela pesca del Friuli-Venezia Giulia (eds) VIII convegno aell'Associazione Italiana Ittiologi Acque Dolci, AIIAD, Codroipo (UD), 30: 159-162 (Italian)

Toscano BJ, Pulcini D, Hayden B, Russo T, Kelly-Quinn M, Mariani S (2010) An ecomorphological framework for the coexistence of two cyprinid fish and their hybrids in a novel environment: hybrid success in a novel environment. Biol J Linn Soc 99:768-783

Tsigenopoulos CS, Kotlík P, Berrebi P (2002) Biogeography and pattern of gene flow among Barbus species (Teleostei: Cyprinidae) inhabiting the Italian Peninsula and neighbouring Adriatic drainages as revealed by allozyme and mitochondrial sequence data: biogeography of adriatic barbus species. Biol J Linn Soc 75:83-99

Vander Zanden MJ, Clayton MK, Moody EK, Solomon CT, Weidel BC (2015) Stable isotope turnover and half-life in animal tissues: a literature synthesis. PloS One 10:e0116182 
von Bertalanffy L (1938) A quantitative theory of organic growth (inquiries on growth laws. II). Hum Biol 10:181-213

Ward JL, Blum MJ, Walters DM, Porter BA, Burkhead N, Freeman B (2012) Discordant introgression in a rapidly expanding hybrid swarm: hybridization and biological invasion in shiners. Evol Appl 5:380-392

Webb PW (1984) Body and fin form and strike tactics of four teleost predators attacking fathead minnow (Pimephales promelas) prey. Can J Fish Aquat Sci 41:157-165

Wheeler A, Jordan DR (1990) The status of the barbel, Barbus barbus (L.) (Teleostei, Cyprinidae), in the United Kingdom. J Fish Biol 37:393-399

Wickham H, François R, Henry L, Müller K (2020) dplyr: A Grammar of Data Manipulation. $\mathrm{R}$ package version 1.0.2. https://CRAN.R-project.org/package=dplyr
Zaccara S, Antognazza CM, Buonerba L, Britton JR, Crosa G (2014) Human-mediated contact zone between endemic and invasive Barbus species (Osteichthyes: Cyprinidae) in a regulated lowland river: genetic inferences and conservation implications. Ital J Zool 81:571-583

Zaccara S, Quadroni S, De Santis V, Vanetti I, Carosi A, Crosa G, Britton RJ, Lorenzoni M (2020) Genetic and phenotypic displacement of an endemic Barbus complex by invasive European barbel Barbus barbus in central Italy. Biol Invasions. https://doi.org/10.1007/s10530-020-02379-2

Zippin C (1956) An evaluation of the removal method of estimating animal populations. Biometrics 12:163-189

Publisher's Note Springer Nature remains neutral with regard to jurisdictional claims in published maps and institutional affiliations. 